University of Nebraska - Lincoln

DigitalCommons@University of Nebraska - Lincoln

Faculty Publications: Department of Entomology

2003

\title{
The Probabilistic Economic Injury Level: Incorporating Uncertainty into Pest Management Decision-Making
}

Robert K. D. Peterson

Montana State University - Bozeman, bpeterson@montana.edu

Thomas E. Hunt

University of Nebraska-Lincoln, thunt2@unl.edu

Follow this and additional works at: https://digitalcommons.unl.edu/entomologyfacpub

Part of the Entomology Commons

Peterson, Robert K. D. and Hunt, Thomas E., "The Probabilistic Economic Injury Level: Incorporating Uncertainty into Pest Management Decision-Making" (2003). Faculty Publications: Department of Entomology. 295.

https://digitalcommons.unl.edu/entomologyfacpub/295

This Article is brought to you for free and open access by the Entomology, Department of at DigitalCommons@University of Nebraska - Lincoln. It has been accepted for inclusion in Faculty Publications: Department of Entomology by an authorized administrator of DigitalCommons@University of Nebraska - Lincoln. 


\title{
The Probabilistic Economic Injury Level: Incorporating Uncertainty into Pest Management Decision-Making
}

\author{
ROBERT K. D. PETERSON ${ }^{1}$ AND THOMAS E. HUNT ${ }^{2}$ \\ Department of Entomology, 333 Leon Johnson Hall, Montana State University, Bozeman, MT 59717-3020
}

J. Econ. Entomol. 96(3): 536-542 (2003)

\begin{abstract}
Despite the recognition that the economic injury level (EIL) is determined by dynamic biological and economic parameters, which can be highly variable and uncertain, there has been little effort to quantify uncertainty and to use estimates of uncertainty in the determination of EILs. In this paper, we define the probabilistic EIL (PEIL) and develop PEILs for two insect pest scenarios: alfalfa weevil larvae, Hypera postica (Gyllenhal), on early bud-stage alfalfa, and bean leaf beetle adults, Cerotoma trifurcata (Forster), on V1-stage soybean. The PEIL is an EIL that reflects its probability of occurrence. The probability of occurrence is determined by incorporating the uncertainty associated with the input variables used to calculate the EIL. We used Monte Carlo simulation, a random sampling technique in which each input variable in the model was sampled repeatedly from a range of possible values based on probability distributions. Each input variable's probability distribution was sampled such that the distribution's shape was reproduced. Then, the variability for each input was propagated into the output of the model so that the model output reflected the probability of values that could occur. This represents the first use of the Monte Carlo technique to determine EILs.
\end{abstract}

KEY WORDS Monte Carlo simulation, bean leaf beetle, alfalfa weevil, soybean, alfalfa

THE ECONOMIC INJURY LEVEL (EIL) is a keystone concept in integrated pest management (IPM). Although its central tenets have never been adequately articulated in a single treatise (Higley and Pedigo 1993, Peterson 1996), IPM clearly is based on the premise that certain levels of pests are tolerable. Consequently, the EIL represents a theoretical foundation for IPM because it provides information on how much pest injury and how many pests are tolerable. Indeed, the EIL concept is primarily responsible for the transition of pest management technology from an identify-and-spray approach to an IPM approach (Peterson and Higley 2002).

The EIL remains an important conceptual and practical tool for IPM in many crop species and systems. Currently, the EIL and the economic threshold (ET) are the most commonly used decision tools in IPM (Pedigo and Higley 1996).

\section{Evolution of the EIL}

Conceptually, the EIL is merely a cost-benefit equation in which the costs (losses associated with managing the pest) are balanced with the benefits (losses prevented by managing the pest). Stern et al. (1959)

\footnotetext{
${ }^{1}$ E-mail: bpeterson@montana.edu.

${ }^{2}$ Department of Entomology, Haskell Agricultural Laboratory, University of Nebraska, Northeast Research and Extension Center, Concord, NE 68728.
}

defined the EIL, but it would be another 13 yr before a formula for calculating the EIL was produced (Stone and Pedigo 1972). Largely because of the accessibility of the EIL model promulgated by Stone and Pedigo (1972), there are now $>200$ published articles on EILs and ETs (Peterson 1996).

The most commonly used equation to determine the EIL is:

$$
E I L=C / V I D K
$$

where $C$ is the management costs per production unit (e.g., \$/ha), $V$ is the market value per production unit (e.g., $\$ / \mathrm{kg}$ ), $I$ is the injury unit per pest equivalent, $D$ is the damage per unit injury (e.g., kg reduction/ha/ injury unit), and $K$ is the proportional reduction in injury with management.

As can be deduced from the equation, the EIL actually represents a level of injury rather than a density of pests. However, numbers of pests per unit area or sample unit often are used because injury is difficult to quantify. Therefore, pest numbers are used as an index for injury.

Conceptual advances in the EIL have occurred primarily through extensions of the Stone and Pedigo (1972) model. The major advances include aesthetic injury levels, multiple-species EILs, and environmental EILs (EEILs). (see Peterson 1996 for a thorough review of conceptual advances.) 


\section{Uncertainty and the EIL}

The EIL includes both economic and biological parameters. All of the parameters used to calculate the EIL are subject to varying amounts of inherent variability and uncertainty. We define variability as an inherent property of nature in which there is heterogeneity of values over time or space. We define uncertainty as lack of knowledge about the true value of a quantity (Cullen and Frey 1999). Perhaps the most obvious uncertain variable is market value per production unit, $V$. A pest management action often is required several weeks before harvest of a crop. Consequently, it becomes necessary to estimate what the market value will be when the producer eventually sells the crop. The proportional reduction in injury with management, $K$, such as the efficacy of a particular pesticide, may not be known or may be quite variable. The injury per pest equivalent, $I$, and damage per unit injury, $D$, may be highly variable because of inherent biological variability, or they may be highly uncertain because of a limited number of studies conducted to characterize those parameters. The management costs per production unit, $C$, are less uncertain because of the ability to incorporate known values for application, pesticide, and fuel costs very close to the time of management action.

\section{Quantifying Uncertainty}

Pest management decision-making nearly always occurs under uncertainty. Aside from uncertainty associated with the EIL parameters, uncertainty associated with sampling pests also occurs. Because a sample represents only an estimate of the true pest density, uncertainty associated with sampling precision and accuracy must be incorporated into the sampling program and resulting decision-making process (Brewer et al. 1994, Buntin 1994).

The EIL typically is calculated by taking mean values for the parameters $C, V, I$, and $D$. The $K$ value often is set to one to indicate $100 \%$ efficacy for the control tactic. Despite the recognition that the EIL is determined by dynamic biological and economic parameters (Pedigo et al. 1986, Peterson 1996), which can be highly variable and uncertain, there has been little effort to quantify uncertainty and to use estimates of uncertainty in the determination of EILs (Peterson 1996). Plant (1986) explored uncertainty associated with the proportion of pest population killed by a pesticide, $K$, and showed that it may have a substantial effect on the calculated EIL. Auld and Tisdell (1987) used economic techniques, such as maximization of net gain, to determine whether to control weed pests when weed densities and the crop-loss function are uncertain.

In this paper, we define the probabilistic EIL (PEIL) and develop PEILs for two insect pest cases: alfalfa weevil larvae, Hypera postica (Gyllenhal), on early bud-stage alfalfa, and bean leaf beetle adults, Cerotoma trifurcata (Forster), on V1-stage soybean. To accomplish this, we used Monte Carlo simulation, a random sampling technique in which each input variable in the model is sampled repeatedly from a range of possible values based on probability distributions. Each input variable's probability distribution is sampled such that the distribution's shape is reproduced. Then, the variability for each input is propagated into the output of the model such that the model output reflects the probability of values that could occur (Vose 1996).

Monte Carlo simulations are used as decision-making tools for many economic and environmental problems. In this article, we present the first use of the Monte Carlo technique to determine EILs. We define the PEIL as an EIL that reflects its probability of occurrence. The probability of occurrence is determined by incorporating the uncertainty associated with the input variables used to calculate the EIL.

\section{Materials and Methods}

\section{Alfalfa Weevil Larvae and Early Bud-Stage Alfalfa}

Data for the $I$ and $D$ variables were obtained from Peterson et al. (1993). Injury per pest equivalent, $I$, was expressed as the total consumption in leaf dry weight by both third and fourth instars (milligram/ larva). Damage per unit injury, $D$, was expressed as yield loss per mg leaf dry weight removed per stem $(\mathrm{kg} / \mathrm{ha} / \mathrm{mg})$. Data for the $K$ variable were obtained from the experience of the authors and Arthropod Management Tests (1999-2001). Percentage control data for alfalfa weevil larvae were obtained from published entries between 1999 and 2001. Only currently registered insecticides from tests conducted in the Midwestern United States were used. Data for the $V$ variable were obtained from Nebraska Agricultural Statistics Service $(2001,2002)$. The model used average monthly prices received by farmers for baled alfalfa hay in Nebraska from January through December 2001. A single management cost, $C$, value of $\$ 24.71 /$ ha $(\$ 10 /$ acre) was used. We used a single value instead of a range of values because we assumed there would be a high certainty of knowledge regarding application costs at the time the management tactic was applied. Table 1 includes a summary for all input data and associated distributions.

\section{Bean Leaf Beetle Adults and V1-Stage Soybean}

Data for the $I$ and $D$ variables were obtained from Hunt et al. (1995) and T. E. Hunt (unpublished data). Injury per pest equivalent, $I$, was expressed as the daily leaf tissue consumption rate (variable) times the number of feeding days (fixed $=14$ ) times the leaf tissue injury expansion coefficient (fixed $=2.81$ ) (Hunt et al 1995). The values and distribution for total leaf area loss per bean leaf beetle adult per day $\left(\mathrm{cm}^{2} /\right.$ beetle/d), or daily leaf tissue consumption rate, were estimated by T. E. Hunt based on personal experience, unpublished data, and data from Hunt et al. (1995). Damage per unit injury, $D$, was expressed as yield loss per square centimeter of leaf tissue loss per plant 
Table 1. Input distributions for probabilistic analysis of economic injury levels

\begin{tabular}{|c|c|c|c|c|}
\hline Input distribution & Distribution type & Parameter & Value & Unit \\
\hline \multicolumn{5}{|l|}{ Alfalfa weevil } \\
\hline \multirow{3}{*}{$\begin{array}{l}\text { Injury per pest } \\
\text { equivalent, I }\end{array}$} & \multirow[t]{3}{*}{ Normal (truncated) } & Mean & 8.09 & \multirow{3}{*}{$\begin{array}{l}\text { mg leaf dry wt. } \\
\text { consumed/larva }\end{array}$} \\
\hline & & $\mathrm{SD}$ & 1.1 & \\
\hline & & Lower bound & 0 & \\
\hline \multirow{3}{*}{$\begin{array}{l}\text { Damage per unit } \\
\text { injury, D }\end{array}$} & \multirow[t]{3}{*}{ Normal (truncated) } & Mean & 7.7 & \multirow{3}{*}{$\begin{array}{l}\mathrm{kg} / \mathrm{ha} \text { yield loss } / \mathrm{mg} \\
\mathrm{dry} \text { wt. removed } / \text { stem }\end{array}$} \\
\hline & & SD & 1.89 & \\
\hline & & Lower bound & 0 & \\
\hline \multirow{3}{*}{$\begin{array}{l}\text { Proportional reduction } \\
\text { in injury with } \\
\text { management, } \mathrm{K}\end{array}$} & \multirow[t]{3}{*}{ Triangular } & Minimum & 90 & \multirow[t]{3}{*}{$\%$ control } \\
\hline & & Likeliest & 95 & \\
\hline & & Maximum & 100 & \\
\hline Market value, $\mathrm{V}$ & Custom & Single points & $\begin{array}{c}0.078,0.079,0.08,0.082,0.082,0.082,0.082 \\
0.085,0.089,0.09,0.096,0.097\end{array}$ & $\$ / \mathrm{kg}$ baled hay \\
\hline Control cost, $\mathrm{C}$ & - & Fixed value & 24.71 & $\$ /$ ha \\
\hline \multicolumn{5}{|l|}{ Bean leaf beetle } \\
\hline \multirow{3}{*}{$\begin{array}{l}\text { Injury per pest } \\
\text { equivalent, I }\end{array}$} & \multirow[t]{3}{*}{ Triangular } & Minimum & 7.08 & \multirow{3}{*}{$\begin{array}{l}\mathrm{cm}^{2} \text { of leaf } \\
\text { tissue/beetle/d* } \\
\text { Injury expansion } \\
\text { Coefficient* feeding } \\
\text { days }\end{array}$} \\
\hline & & Likeliest & 8.26 & \\
\hline & & Maximum & 17.31 & \\
\hline \multirow{3}{*}{$\begin{array}{l}\text { Damage per unit } \\
\text { injury, D }\end{array}$} & \multirow[t]{3}{*}{ Normal (truncated) } & Mean & 1.33 & \\
\hline & & SD & 0.27 & \multirow[t]{2}{*}{ leaf tissue loss/plant } \\
\hline & & Lower bound & 0 & \\
\hline \multirow{3}{*}{$\begin{array}{l}\text { Proportional reduction } \\
\text { in injury with } \\
\text { management, } \mathrm{K}\end{array}$} & \multirow[t]{3}{*}{ Triangular } & Minimum & 95 & \multirow[t]{3}{*}{$\%$ control } \\
\hline & & Likeliest & 97.5 & \\
\hline & & Maximum & 100 & \\
\hline \multirow[t]{3}{*}{ Market value, $\mathrm{V}$} & \multirow[t]{3}{*}{ Triangular } & Minimum & 0.14 & \multirow[t]{3}{*}{$\$ / \mathrm{kg}$} \\
\hline & & Likeliest & 0.15 & \\
\hline & & Maximum & 0.19 & \\
\hline Control cost, $\mathrm{C}$ & - & Fixed value & 24.71 & $\$ /$ ha \\
\hline
\end{tabular}

$\left(\mathrm{kg} / \mathrm{ha} / \mathrm{cm}^{2}\right)$. Data for the $K$ variable were estimated based on the experience of T. E. Hunt. The insecticidal control for bean leaf beetle adults on seedling soybean in Nebraska typically ranges between 95 and $100 \%$. Data for the $V$ variable were obtained from Minneapolis Grain Exchange (2001). The model used national soybean average weekly prices per bushel from January through December 2001. As with the alfalfa weevil analysis, a single management cost, $C$, value of $\$ 24.71 /$ ha ( $\$ 10 /$ acre) was used. Table 1 includes a summary for all input data and associated distributions.

\section{Analysis}

We used Monte Carlo analysis (Crystal Ball 2000 ver. 5.2; Decisioneering, Denver, CO) to evaluate input variables and their effect on the EIL. We performed 10,000 iterations for distributional analysis using the input assumptions from Table 1. The software model calculated 10,000 EILs by randomly selecting a value from the distributions of each variable based on their probability of occurrence. The probability of occurrence is determined by incorporating the uncertainty associated with the input variables used to calculate the EIL. Each input variable's probability distribution was sampled such that the distribution's shape was reproduced. Then, the variability for each input was propagated into the output of the model so that the model output reflected the probability of values that could occur.
For example, to calculate EILs for alfalfa weevil larvae on early-bud stage alfalfa, the equation used was:

$$
E I L=C / V I D K,
$$

where $E I L$ is the alfalfa weevil larvae per stem, $C$ is the insecticide and application cost per hectare $(\$ / \mathrm{ha}), V$ is the market value per $\mathrm{kg}(\$ / \mathrm{kg}), I$ is the total consumption in leaf dry weight by both third and fourth instars (milligrams/larva), $D$ is the yield loss per milligram leaf dry weight removed per stem $(\mathrm{kg} / \mathrm{ha} / \mathrm{mg})$, and $K$ is the percent control with insecticide. The software model calculated 10,000 EILs using the above equation. For each EIL calculation, the value for $C$ was held constant at $\$ 24.71 /$ ha and the values for $V, I, D$, and $K$ were selected randomly based on their probabilities of occurrence, as determined from their distributions. For example, the values for $D$ were selected randomly from a truncated normal distribution with a mean of $7.7 \mathrm{~kg} /$ ha yield loss $/ \mathrm{mg}$ dry weight removed/ stem and an SD of 1.89 (Table 1). This means that the majority of values randomly selected and used to calculate an EIL were selected within 1 SD of the mean. The values representing the upper and lower $5 \%$ of the distributions were selected randomly, but only were selected in $5 \%$ of the resulting 10,000 EIL calculations. Because the variability for each input is propagated into the output of the model, the model output reflects the probability of values that could occur. Therefore, the output is a distribution of EIL values (Fig. 1). All presentations in this paper of input values and distributions and output statistics and distributions follow 


\section{Forecast: Alfalfa Weevil ElLs}

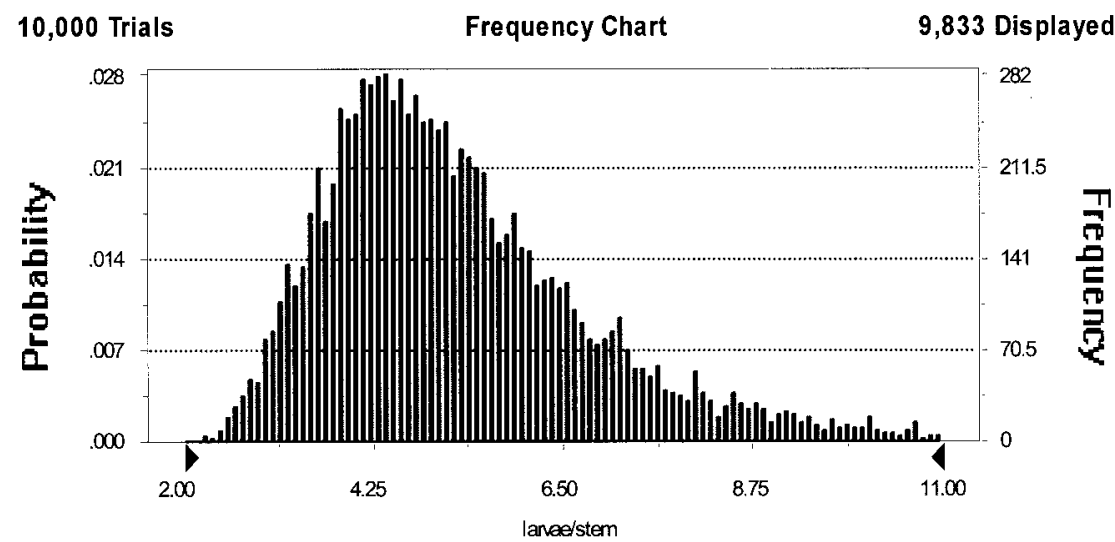

Forecast: BLB EIL

10,000 Trials Frequency Chart 9,873 Displayed

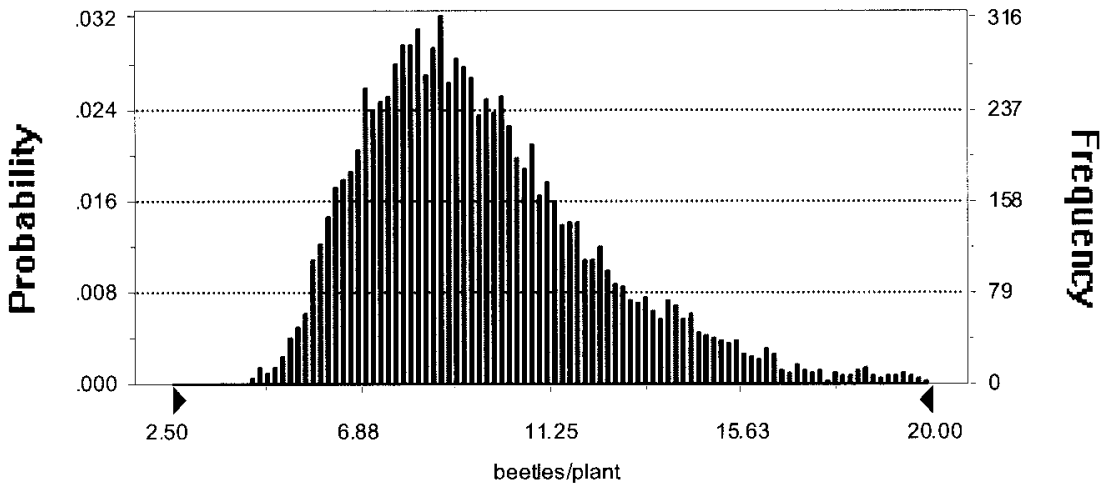

Fig. 1. PEIL distributions for the alfalfa weevil (top) and the bean leaf beetle (bottom).

best practices and guiding principles for Monte Carlo analyses (U.S. EPA 1997).

\section{Results}

The distribution of EIL values determined from 10,000 iterations of input values was lognormal for both alfalfa weevil and bean leaf beetle simulations (Fig. 1). The statistical summaries for both simulations reveal that the distributions have high kurtosis (peakedness) and positive skewness, indicative that high-end estimates of EILs are atypical events (Table 2).

\section{Contributors to Variance}

Alfalfa Weevil. The sensitivity analysis measured by contribution to variance for each input value indicated that the primary contributor to variance was damage per unit injury, $D$ (Table 3 ). Injury per alfalfa weevil larva, $I$, contributed $21.1 \%$ to overall variance, whereas market value, $V$, and percent control, $K$, contributed 5.1 and $0.4 \%$, respectively.
Bean Leaf Beetle. As with the alfalfa weevil scenario, the sensitivity analysis indicated that the primary contributor to variance was damage per unit injury, $D$ (Table 3 ). However, injury per bean leaf beetle adult, $I$, contributed $40.8 \%$ to overall variance. Market value, $V$, and percent control, $K$, contributed 5 and $0.1 \%$, respectively.

Understanding which variables contribute to variance in EILs can provide important insights into future

Table 2. Summary statistics for each case simulation

\begin{tabular}{lcr}
\hline \hline & \multicolumn{2}{c}{ Values } \\
\cline { 2 - 3 } Output statistics & Alfalfa weevil & $\begin{array}{c}\text { Bean leaf } \\
\text { beetle }\end{array}$ \\
\hline Trials & 10,000 & 10,000 \\
Mean & 5.35 & 9.82 \\
Median & 4.94 & 9.22 \\
SD & 2.14 & 10.21 \\
SE & 0.02 & 0.03 \\
Skewness & 14 & 2.18 \\
Kurtosis & 596 & 15.11 \\
Range & $1.98-117.39$ & $3.88-51.86$ \\
\hline
\end{tabular}


Table 3. Input variables and their percentage contribution to variance of EIL model outputs

\begin{tabular}{lcc}
\hline \hline \multirow{2}{*}{ Variable } & \multicolumn{2}{c}{ \% Contribution to variance } \\
\cline { 2 - 3 } & Alfalfa weevil & Bean leaf beetle \\
\hline Damage per unit & 72.1 & 54.1 \\
$\quad$ injury, D & 22.3 & 40.8 \\
Injury per insect, I & 5.1 & 5 \\
Market value, V & 0.5 & 0.1 \\
Percent control, K & & \\
\hline
\end{tabular}

research direction and prioritization of effort. For example, given that injury per pest, $I$, is responsible for $40.8 \%$ of the variability in EILs for the bean leaf beetle, future research efforts should be directed toward reducing uncertainty associated with that variable. Experimental variability associated with measurements of adult bean leaf beetle feeding most likely is large and may be much larger than biological variability. Because we do not know how much of the variability is attributable to biological versus experimental variability, future efforts should attempt to delineate the two so that the variability that is used in the EIL calculation reflects on the inherent biological variability.

Similarly, research efforts should be directed toward better understanding of damage per unit injury, $D$, for both bean leaf beetle and alfalfa weevil. Conversely, little research effort needs to be expended to reducing uncertainty associated with estimates of market value, $V$, and percent control, $K$, because they contribute very little variance to the final EIL values. The $D$ variables for both simulations represent a single study replicated twice. For example, the $D$ variable for alfalfa weevil was based on a field study conducted over only two field seasons in eastern Nebraska. Consequently, variability and uncertainty are large. Although there will always be some inherent biological variability, additional studies would help to better understand both biological and experimental variability and uncertainty, resulting in more certainty in the EIL estimations.

\section{Pest Management Decision-Making Using PEILs}

Percentiles of EILs from the bean leaf beetle simulation indicate that the median value was 9.22 beetles/plant (Table 4 ). This value was only 0.21 beetles/ plant less than the mean EIL of 9.43, which represented a typical value determined by using mean values for $I, D, V$, and $K$ (see Table 1 for mean values). By incorporating uncertainty into the calculation of EILs, the EIL is effectively reduced by only 0.21 beetles/plant if the median value is used as the decision threshold. Percentiles of EILs from the alfalfa weevil simulation revealed that the median value was 4.94 larvae/stem (Table 4 ). This value was very similar to the mean EIL of 4.91 larvae/stem, which represented a value determined by using mean values for the input variables.

The practical value of the PEIL is that multiple EIL values ranked as percentiles of the Monte Carlo dis-
Table 4. Ranked percentiles of EIL's determined from case simulations

\begin{tabular}{ccc}
\hline \hline & \multicolumn{2}{c}{ Values } \\
\cline { 2 - 3 } Percentile & Alfalfa weevil & Bean leaf beetle \\
\hline 0 & 1.98 & 3.88 \\
5 & 3.19 & 6.06 \\
10 & 3.49 & 6.59 \\
15 & 3.73 & 6.97 \\
20 & 3.93 & 7.36 \\
25 & 4.10 & 7.7 \\
30 & 4.27 & 8 \\
35 & 4.45 & 8.29 \\
40 & 4.60 & 8.6 \\
45 & 4.77 & 8.9 \\
50 & 4.94 & 9.22 \\
55 & 5.12 & 9.55 \\
60 & 5.31 & 9.91 \\
65 & 5.52 & 10.3 \\
70 & 5.77 & 10.73 \\
75 & 6.06 & 11.21 \\
80 & 6.42 & 11.82 \\
85 & 6.89 & 12.58 \\
90 & 7.52 & 13.72 \\
95 & 8.78 & 15.4 \\
100 & 117.39 & 51.86 \\
\hline
\end{tabular}

tributional analysis allow the decision maker to choose her or his level of risk within an IPM program (Table $5)$. For example, if the decision maker is risk averse (i.e., she does not want to risk economic injury even if it means spraying in the absence of economic injury) and needs to decide which threshold to use for alfalfa weevil, she may choose a PEIL of 4.1 larvae/ stem. This PEIL represents the 25th percentile of values as determined from the model output. The use of 4.1 lar$\mathrm{vae} / \mathrm{stem}$ as the PEIL ensures that an EIL $<4.1$ will occur only $25 \%$ of the time; therefore, the decision maker will use a sufficiently conservative value $75 \%$ of the time. The risk to the decision maker is $25 \%$, and her certainty or confidence is $75 \%$. Conversely, if the decision maker is risk seeking (i.e., she is willing to incur modest economic injury and avoid the cost of spraying), she may choose the PEIL at the 75th percentile. The PEIL of 6.1 larvae/stem will be sufficiently conservative only $25 \%$ of the time.

The choice of risk level is dependent on numerous factors. These include, but are not limited to, confidence in the knowledge and data underlying the PEILs and the type and economic value of the production system. For example, in an alfalfa production

Table 5. Probabilistic EILs for alfalfa weevil and bean leaf beetle

\begin{tabular}{lrrrrrrr}
\hline \hline \multirow{2}{*}{ Pest } & \multicolumn{6}{c}{ PEIL for each risk level $^{a}$} \\
\cline { 2 - 8 } & $5 \%$ & $10 \%$ & $25 \%$ & $50 \%$ & $75 \%$ & $90 \%$ & $95 \%$ \\
\hline Alfalfa weevil & $3.2^{b}$ & 3.5 & 4.1 & 4.9 & 6.1 & 7.5 & 8.8 \\
Bean leaf beetle & $6.1^{c}$ & 6.6 & 7.7 & 9.2 & 11.2 & 13.7 & 15.4 \\
\hline
\end{tabular}

${ }^{a}$ Percentage value reflects the level of risk accrued if the decision maker uses the respective PEIL value. For example, if 4.1 larvae/stem is used by the decision maker for alfalfa weevil, then there is a $25 \%$ risk that the actual EIL will be lower.

${ }^{b}$ Alfalfa weevil larvae/stem on early-bud stage alfalfa.

${ }^{c}$ Bean leaf beetle adults/plant on V1-stage soybean. 
system where the alfalfa will be sold as premium hay for horses, the decision maker may use a more conservative EIL than a decision maker in a system where the alfalfa only will be used for on-farm livestock. Because the contribution to bean leaf beetle EIL variance from the $I$ (injury per pest) variable is so large, a decision maker may be satisfied with using the median EIL value because he may be concerned that the variance primarily is from experimental variability, not inherent biological variability.

Like the majority of conceptual advances in the EIL, the PEIL is an extension of the Stone and Pedigo (1972) model. The PEIL adds value to pest management decision making because it formally and quantitatively incorporates uncertainty into the EIL. Furthermore, it allows the decision maker to choose an EIL based on her or his desired level of risk. Consequently, the PEIL is a more flexible tool than traditional economic thresholds.

Although the PEIL adds value to pest management decision making, it potentially represents substantial limitations. The probabilistic distribution of PEIL values reflects both experimental and biological variability for $I, D$, and $K$. Understanding the contribution from each type of variability to the PEIL values is important because PEILs that incorporate large experimental variability do not only represent biological variability and therefore are not accurate. To better understand both types of variability, experiments would need to be replicated several times and the distributions generated from a group of mean values. However, replication of injury per pest and damage per pest injury experiments is expensive. Typically, studies designed to determine EILs are replicated only twice (once per growing season over two seasons), which would produce only two mean values.

PEILs are more complex than nominal thresholds or simple calculated EILs. The ability of typical IPM decision makers, such as individual growers and consultants, to calculate PEILs would be limited because their calculation requires relatively expensive and sophisticated Monte Carlo simulation software. Therefore, care must be taken to implement them properly in an IPM program so that decision makers could gain maximum value from using them. Indeed, the sophistication of EILs must be balanced with their accessibility to the end user (Peterson 1996). Therefore, the most valuable implementation strategy for PEILs most likely would be for university extension specialists to calculate them each year (because of changes in anticipated crop market values), convert them to economic thresholds, and present them to decision makers as a grid similar to Table 5. Using this presentation style, IPM decision makers personally can choose an economic threshold based on their acceptable level of risk.

\section{Acknowledgments}

We thank S. Blodgett, G. Johnson, and A. Lenssen (Montana State University) for reviews of earlier versions of this manuscript. This manuscript has been assigned Journal Series
No. 2002-52, MT Agricultural Experiment Station, Montana State University, and Contribution 1141 of the Entomology Department, Journal Series number 13826, University of Nebraska-Lincoln Agricultural Research Division Contribution.

\section{References Cited}

Auld, B. A., and C. A. Tisdell. 1987. Economic thresholds and response to uncertainty in weed control. Agric. Syst. 25: $219-227$.

Brewer, M. J., D. E. Legg, and J. E. Kaltenbach. 1994. Comparisons of three sequential sampling plans using binomial counts to classify insect infestation with respect to decision thresholds. Environ. Entomol. 23: 812-826.

Buntin, G. D. 1994. Developing a primary sampling program, pp. 99-115. In L. P. Pedigo and G. D. Buntin (eds.), Handbook of sampling methods for arthropods in agriculture. CRC, Boca Raton, FL.

Cullen, A. C., and H. C. Frey. 1999. Probabilistic techniques in exposure assessment: a handbook for dealing with variability and uncertainty in models and inputs. Plenum, New York.

[EPA] U.S. Environmental Protection Agency. 1997. Guiding principles for Monte Carlo analysis. EPA 630/R-97/ 001. U.S. Environmental Protection Agency, Washington, DC.

[ESA] Entomological Society of America. 1999. F6, F7, F9, and F12. In K. Saxena [ed.], Arthropod Management Tests, vol. 24. Entomological Society of America, Lanham, MD. (http://www.entsoc.org/Protected/AMT/amt1999/ index.html)

[ESA] Entomological Society of America. 2000. F2, F5, F6, and F8. In K. Saxena [ed.], Arthropod Management Tests, vol. 25. Entomological Society of America, Lanham, MD. (http://www.entsoc.org/Protected/AMT/AMT25/index. asp)

[ESA] Entomological Society of America. 2001. F1 and F3. In K. Saxena [ed.], Arthropod Management Tests, vol. 26. Entomological Society of America, Lanham, MD. (http:// www.entsoc.org/Protected/AMT/AMT26/index.asp)

Higley, L. G., and L. P. Pedigo. 1993. Economic injury level concepts and their use in sustaining environmental quality. Agric. Ecosyst. Environ. 46: 233-243.

Hunt, T. E., L. G. Higley, and J. F. Witkowski. 1995. Bean leaf beetle injury to seedling soybean: consumption, effects of leaf expansion, and economic injury levels. Agron. J. 87: 183-188.

[MGEX] Minneapolis Grain Exchange. 2001. National Soybean Index (http://www.mgex.com).

[NASS] Nebraska Agricultural Statistics Service. 2001, 2002. Nebraska Agri-Facts, Nebraska Agricultural Statistics Service (http://www.agr.state.ne.us/agstats/index.htm).

Pedigo, L. P., and L. G. Higley. 1996. Introduction to pest management and thresholds, pp. 3-9. In Economic thresholds for integrated pest management. University of Nebraska Press, Lincoln, NE.

Pedigo, L. P., S. H. Hutchins, and L. G. Higley. 1986. Economic injury levels in theory and practice. Annu. Rev. Entomol. 31: 341-368.

Peterson, R.K.D. 1996. The status of economic-injury-level development, pp. 151-178. In L. G. Higley and L. P. Pedigo (eds.), Economic thresholds for integrated pest management. University of Nebraska Press, Lincoln, NE.

Peterson, R.K.D., and L. G. Higley. 2002. Economic decision levels, pp. 228-230. In D. Pimentel (ed.), Encyclopedia of pest management. Marcel Dekker, New York. 
Peterson, R.K.D., S. D. Danielson, and L. G. Higley. 1993. Yield responses of alfalfa to simulated alfalfa weevil injury and development of economic injury levels. Agron. J. 85: $595-601$.

Plant, R. E. 1986. Uncertainty and the economic threshold. J. Econ. Entomol. 79: 1-6.

Stern, V. M., R. F. Smith, R. van den Bosch, and K. S. Hagen. 1959. The integrated control concept. Hilgardia 29: 81101.
Stone, J. D., and L. P. Pedigo. 1972. Development and economic-injury level of the green cloverworm on soybean in Iowa. J. Econ. Entomol. 65: 197-201.

Vose, D. 1996. Quantitative risk analysis: a guide to Monte Carlo simulation. Wiley, New York.

Received for publication 9 August 2002; accepted 31 December 2002. 